\title{
Environmentally associated ticks (Acari: Ixodidae) in Campo Grande, Mato Grosso do Sul, Brazil
}

\author{
Carrapatos (Acari: Ixodidae) associados com o ambiente em Campo Grande, Mato Grosso do Sul, Brasil \\ Marcos Valério Garcia ${ }^{1}$; Dayana Campelo da Silva ${ }^{1}$; Robson Ferreira Cavalcante de Almeida ${ }^{1}$; \\ Rodrigo Casquero Cunha ${ }^{1}$; Jaqueline Matias ${ }^{1}$; Jacqueline Cavalcante Barros ${ }^{1}$; \\ Renato Andreotti ${ }^{1 *}$; Matias Pablo Juan Szabó ${ }^{2}$
}

${ }^{1}$ Animal Health Laboratory, Embrapa Beef Cattle, Campo Grande, MS, Brazil

${ }^{2}$ Department of Veterinary Pathology, Faculdade de Medicina Veterinária, Universidade Federal de Uberlândia - UFU, Uberlândia, MG, Brazil

Received November 26, 2012

Accepted February 19, 2013

\begin{abstract}
Herein, we report tick species found on wild and domestic animals and in the environment during a one-year sampling period at the Brazilian Farming Research Company beef cattle unit (Embrapa Beef Cattle), which is located within the urban area of Campo Grande, Mato Grosso do Sul, Brazil. From 55 wild hosts including six different species (Nasua nasua, Cebus spp., Cerdocyon thous, Myrmecophaga tridactyla, Tamandua tetradactyla and Dasyprocta aguti), 323 ticks were collected. Amblyomma ovale ticks were found solely on coatis, and Amblyomma nodosum was identified solely on anteaters. No ticks were found on capuchin monkeys. However, Amblyomma cajennense was found on all parasitized host species with the exception of capuchin monkeys. Giant anteaters displayed the highest infestation abundance, with a mean of 53 ticks/animal. Environmental sampling yielded 166 adult $A$. cajennense ticks. The tick species found on domestic animals (Rhipicephalus (Boophilus) microplus, $R$. sanguineus, Dermacentor nitens and $A$. cajennense) were those typically found on these hosts in Brazil. The most prevalent tick species, A. cajennense, was found on both wild and domestic animals and was also prevalent in the environment. Thus, this tick species is the primary vector that allows pathogens to bridge wild and domestic animals in the Cerrado.
\end{abstract}

Keywords: Ticks, wild animals, urban area, Campo Grande, Mato Grosso do Sul.

\section{Resumo}

Neste trabalho são descritas as espécies de carrapatos de animais selvagens e domésticos e do ambiente coletados por um ano na EMBRAPA Gado de Corte localizado na área urbana de Campo Grande, Mato Grosso do Sul, Brasil. Dos 55 hospedeiros selvagens de seis espécies diferentes (Nasua nasua, Cebus spp., Cerdocyon thous, Myrmecophaga tridactyla, Tamandua tetradactyla e Dasyprocta aguti) foram coletados 323 carrapatos. Amblyomma ovale foi encontrado apenas em quatis e Amblyomma nodosum apenas sobre tamanduás. Nenhum carrapato foi encontrado sobre macacos-prego. Por outro lado, Amblyomma cajennense foi encontrado em todos os hospedeiros com exceção dos macacos-pregos. A maior abundancia de infestação foi aquela em tamanduás-bandeira com média de 53 carrapatos/animal. No ambiente foram capturados 166 carrapatos, todos da espécie $A$. cajennense. As espécies de carrapatos em animais domésticos (Rhipicephalus (Boophilus) microplus, Rhipicephalus sanguineus, Dermacentor nitens e A. cajennense) foram aquelas características nestes hospedeiros no Brasil. De forma geral a espécie de carrapato $A$. cajennense foi a mais prevalente sendo encontrada em animais domésticos e selvagens bem como no ambiente. Portanto, esta é a principal espécie de vetor a estabelecer uma ponte para bioagentes patogênicos entre animais domésticos e selvagens.

Palavras-chave: Carrapato, animais selvagens, área urbana, Campo Grande, Mato Grosso do Sul.

\footnotetext{
${ }^{*}$ Corresponding author: Renato Andreotti

Animal Health Laboratory, Embrapa Beef Cattle,

Av. Radio Maia, 830, Vila Popular, CEP 79106-550,

Campo Grande, MS, Brazil

e-mail: renato.andreotti@embrapa.br
} 


\section{Introduction}

The tick fauna of Brazil is estimated to comprise 61 species, mostly from the Amblyomma genera (DANTAS-TORRES et al., 2009), although this number will certainly increase as new species are described. Concurrently, the country has continental dimensions, and the fauna of individual states are certainly different from each other, but this matter has not been thoroughly studied thus far.

The state of Mato Grosso do Sul in midwestern Brazil has a territory of $357.125 \mathrm{~km}^{2}$ and a very rich biodiversity in its dominant biomes, a savannah ("Cerrado") and a huge floodplain (Pantanal). The state is also devoted to agriculture, including beef cattle production. Thus, wildlife and domestic animals frequently share the same environment, potentiating the mixing of parasites such as ticks. This mixing is a matter of concern as ticks are important infectious disease vectors for both animals and humans, and the species distribution of these parasites is linked to specific diseases (JONGEJAN; UILENBERG, 2004).

Twenty tick species from Mato Grosso do Sul have been described (GARCIA et al., 2012); however, this number is an underestimate, because a systematic evaluation over the state has not been conducted. Campo Grande, the capital of this state, has 786,797 inhabitants and is located within the Cerrado biome. There are several natural areas within the urban zone, particularly at the outskirts, and wild animals are common, as indicated by the high frequency of road-killed animals such as capybaras, wild Canidae and anteaters.

Herein, we report tick species found at the Brazilian Farming Research Company beef cattle unit (Embrapa Beef Cattle), which is located within the urban area of Campo Grande.

\section{Materials and Methods}

\section{Sampling location and period}

The study was conducted in the urban area of the Campo Grande municipality, Mato Grosso do Sul, Brazil. The study location is within the Brazilian Farming Research Company beef cattle unit (Embrapa Beef Cattle), which is located $15 \mathrm{~km}$ away from the city center. This unit comprises 3,081 hectares and includes buildings, pastures and native vegetation. Three sampling sites were chosen for the study, two in areas with native vegetation and one pasture (Table 1 and Figure 1).

\section{Tick sampling}

Ticks were collected from wild and domestic animals and from the environment (host-questing ticks) and were either placed in $70 \%$ ethanol (adults) or taken alive to the laboratory and kept at $28{ }^{\circ} \mathrm{C}$ and $80 \%$ relative humidity (nymphs). Ticks from each animal and each location were stored in individual bottles until the species were identified.

Mid-sized wild mammals were captured during four consecutive seasons, with one campaign in each season (winter $-15^{\text {th }}$ to $30^{\text {th }}$ of
August 2011; spring - $10^{\text {th }}$ to $25^{\text {th }}$ of November 2011; summer $-14^{\text {th }}$ to $26^{\text {th }}$ of February 2012; and autumn $-15^{\text {th }}$ to $30^{\text {th }}$ of May 2012). During each campaign, eight Tomahawk traps were used; six small traps $(40 \times 45 \times 1.10 \mathrm{~cm})$ were baited with fruit (banana, pear, apple, papaya, mango, tomatoes), whereas two large traps $(70 \times 45 \times 1.20 \mathrm{~cm})$ were baited with meat. The traps were baited in the evening and examined every morning. Three small traps were used at locations 1 and 2 at sites with wild animal vestiges (scat and tracks), whereas the two large traps were used at location 3 to capture the wild Canidae that are frequently observed in the pasture. The captured animals were anesthetized using a mixture of tiletamine and zolazepan (Cloridrato de Tiletamina $125 \mathrm{mg}$, Virbac, Cloridrato Zolazepan $125 \mathrm{mg}$, Virbac) according to the manufacturer's recommendation. The entire body of each animal was thoroughly examined for ticks by visual inspection and with the aid of a comb. Examined animals were marked by cutting

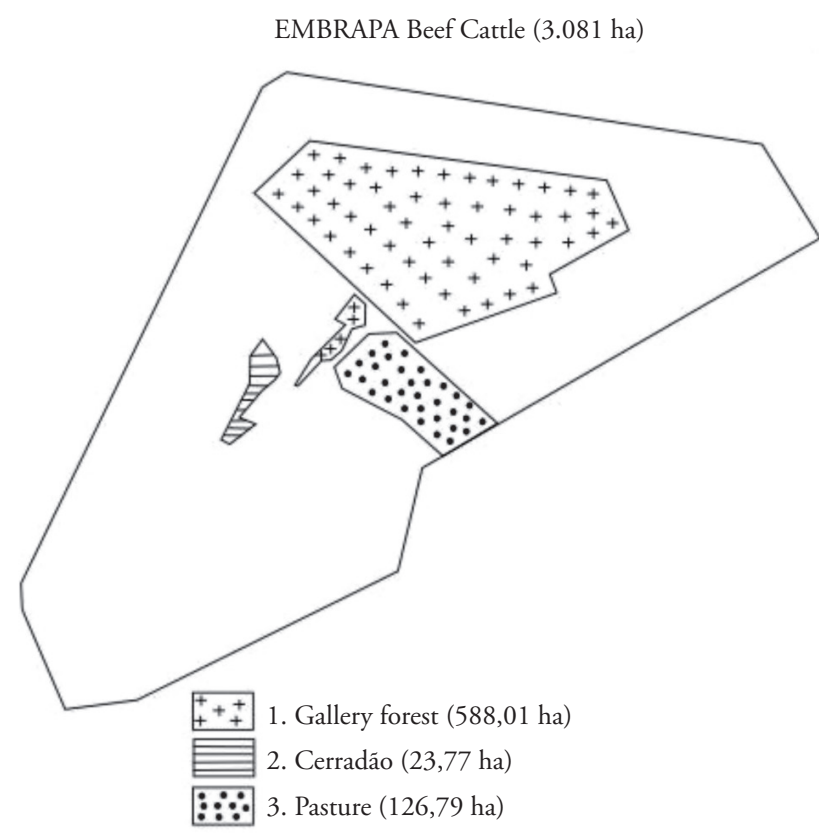

Figure 1. Representative Map of Embrapa Beef Cattle, showing the three study areas and their respective sizes, Campo Grande, Mato Grosso do Sul, Brazil.

Table 1. Tick sampling location and vegetation within the Brazilian Farming Research Company - Embrapa, Campo Grande, Mato Grosso do Sul, Brazil, 2011-2012.

\begin{tabular}{cccc}
\hline Location & Coordinates & Altitude (m) & Vegetation \\
\hline 1 & S $20^{\circ} 442470^{\prime}$ & 519.6 & Gallery forest $^{1}$ \\
& W $54^{\circ} 724960^{\prime}$ & & \\
2 & S $20^{\circ} 443084^{\prime}$ & 504.4 & Cerradão $^{2}$ \\
& W $54^{\circ} 729021^{\prime}$ & & \\
3 & S $20^{\circ} 442576^{\prime}$ & 530.0 & Pasture $^{3}$ \\
& W $54^{\circ} 722066^{\prime}$ & & \\
\hline
\end{tabular}

\footnotetext{
'Narrow forest strips found along streams and flanked by grasslands or Cerrados; ${ }^{2}$ Almost closed woodland with crown cover of $50 \%$ to $90 \%$, consisting of trees, often of 8-12 m or even taller, casting considerable shade so that the ground vegetation layer is greatly reduced; ${ }^{3}$ Non-native pasture (Brachiaria decumbens). Cerrado phytophysignomies according to Oliveira Filho and Ratter (2002).
} 
their fur to avoid repeated examination of the same animal during each campaign. The hosts were released at the capture site after complete recovery from the anesthesia. The Brazilian Environment Institute (IBAMA, Permit No. 29430-1) authorized the wild animal capture, and the permits are on file under one author's name (Andreotti, R.).

Host-questing ticks from the environment were collected with $\mathrm{CO}_{2}$ traps that were used as previously described (OLIVEIRA et al., 2000). Briefly, approximately $200 \mathrm{~g}$ of dry ice was placed in the middle of a $50 \times 50 \mathrm{~cm}$ white flannel cloth. The cloth had doublesided adhesive tape along its perimeter and was laid on the ground to let the ice sublimet for two hours. At each campaign, $10 \mathrm{CO}_{2}$ traps were used at each sampling site ( $\mathrm{n}=30 \mathrm{CO}$ traps), with a distance from 20 to $80 \mathrm{~m}$ between traps. As with the Tomahawk traps, the $\mathrm{CO}_{2}$ traps were placed in areas with wild animal vestiges or where wild animals were occasionally observed (pasture).

Random tick samples were collected from domestic animals during the study year. For this purpose, chickens, dogs, cattle and horses on the property were inspected.

\section{Tick identification}

Adult ticks were identified according to Barros-Battesti et al. (2006), and Amblyomma nymphs were reared to the adult stage in the laboratory.

\section{Results}

In total, 55 midsized mammals from six different species (Nasua nasua - Coati; Cebus spp. - Capuchin; Cerdocyon thous - Crabeating Fox; Myrmecophaga tridactyla - Giant Anteater; Tamandua tetradactyla - Southern Anteater; Dasyprocta aguti - Agouti) were captured (Table 2). With the exception of capuchin monkeys, all of the animals were tick-infested (the prevalence of tick infestation was $0 \%$ and $100 \%$, respectively, Table 2). Overall, 323 nymphs and adults from three tick species were collected from the animals. Of the 141 engorged nymphs, 85 (60\%) molted to $A$. cajennense adults. Flat nymphs $(\mathrm{n}=103)$ were fed on rabbits in the laboratory, and $21(25 \%)$ molted to $A$. cajennense adults.

Amblyomma ovale ticks were found solely on coatis, and A. nodosum were found solely on anteaters. However, $A$. cajennense was found on all host species. Giant anteaters displayed the highest infestation abundance, with a mean of 53 specimens/animal.
Environmental sampling yielded 166 adult $A$. cajennense ticks. Most adult ticks were captured during the spring (46.4\%) and summer $(32.5 \%)$. Of these, $34.9 \%$ were female and $65.1 \%$ were male (Table 3).

An inspection of four dogs living unrestrained on the property yielded eight adult Rhipicephalus sanguineus and $12 \mathrm{~A}$. cajennense nymphs. The only tick species found on the 39 crossbred bovines (Zebu x Holstein) was Rhipicephalus (B.) microplus, and various stages of both Dermacentor nitens and $A$. cajennense were found on the 15 horses. Ticks were not found on chickens or in their pens.

Tick specimen samples collected in the present study were deposited in the Embrapa Beef Cattle Tick Collection, Embrapa Campo Grande (accession numbers: 23-47).

\section{Discussion}

The results showed a high prevalence of tick infestation of wild animals within the urban areas of Campo Grande. Even within the same area, some tick species were clearly linked to wild hosts, whereas others were linked solely to domestic animals. However, the most prevalent tick species, $A$. cajennense, was found on both wild and domestic animals and was prevalent in the environment.

Overall, the high prevalence and abundance of $A$. cajennense appears to rely on its adaptation to the Cerrado (SZABÓ et al., 2007; VERONEZ et al., 2010) and its wide host range, which includes both domestic and wild hosts for the most host-specific stage, the adult (ARAGÃO, 1936; PEREIRA et al., 2000; LABRUNA et al., 2001). Thus, this tick is the primary vector for tick-borne pathogens that pass between wild and domestic animals in the Cerrado. This tick species is also aggressive toward humans, and bites are frequent (GUGLIELMONE et al., 2006). Not surprisingly, it is the main vector of Rickettsia rickettsii, the causative agent of a lethal spotted fever in Brazil (LABRUNA, 2009).

The second most abundant tick, $A$. ovale, was found solely in the adult stage on coatis. This tick species has a preference for carnivores such as coatis in its adult stage (LABRUNA et al., 2005), and larvae and nymphs are believed to parasitize small rodents (MARTINS et al., 2012), which were not sampled in this work. Additionally, A. ovale was not found on the other carnivores (Crabeating fox) that are known to host this tick species (LABRUNA et al., 2005). We speculate that this finding was most likely due to the low numbers of hosts that were captured. This tick species is also known to bite humans (GUGLIELMONE et al., 2006) and to harbor Atlantic rainforest Rickettsia (SZABÓ et al. 2013, in press),

Table 2. Tick numbers (N), species and abundance (A) on wild animals captured in the Brazilian Farming Research Company - Embrapa, Campo Grande, Mato Grosso do Sul, Brazil, 2011-2012.

\begin{tabular}{|c|c|c|c|c|c|c|}
\hline \multirow{2}{*}{ Hosts (n) } & \multicolumn{2}{|c|}{ A. cajennense } & \multirow{2}{*}{$\frac{\text { A. ovale }}{\mathrm{A}}$} & \multirow{2}{*}{$\frac{\text { A. nodosum }}{\mathrm{A}}$} & \multirow{2}{*}{$\frac{\text { Amblyomma spp. }}{\mathrm{N}}$} & \multirow{2}{*}{ Abundance (\%) } \\
\hline & $\mathbf{A}$ & $\mathbf{N}$ & & & & \\
\hline Coati (35) & 10 & 46 & 38 & 0 & 37 & 3.7 \\
\hline Capuchin (10) & 0 & 0 & 0 & 0 & 0 & - \\
\hline Crab-eating Fox (04) & 7 & 15 & 0 & 0 & 25 & 11.8 \\
\hline Giant Anteater (02) & 0 & 79 & 0 & 9 & 18 & 53.0 \\
\hline Southern Anteater (02) & 1 & 0 & 0 & 13 & 20 & 17.0 \\
\hline Agouti (02) & 1 & 1 & 0 & 0 & 3 & 2.5 \\
\hline
\end{tabular}

\footnotetext{
$\%$ - percentage.
} 
Table 3. Host-seeking $A$. cajennense ticks collected from the environment during four consecutive seasons in the Brazilian Farming Research Company - Embrapa, Campo Grande, Mato Grosso do Sul, Brazil, 2011-2012.

\begin{tabular}{ccccc}
\hline \multirow{3}{*}{ Tick sex } & \multicolumn{4}{c}{ Sampling time } \\
\cline { 2 - 5 } & Winter & Spring & Summer & Autumn \\
& $\mathbf{2 0 1 1}$ & $\mathbf{2 0 1 1}$ & $\mathbf{2 0 1 2}$ & $\mathbf{2 0 1 2}$ \\
\hline Female & 10 & 22 & 16 & 10 \\
Male & 8 & 55 & 38 & 7 \\
Total & 18 & 77 & 54 & 17 \\
\hline
\end{tabular}

an agent of a novel rickettsiosis in Brazil (SPOLIDORIO et al., 2010).

The third tick species, $A$. nodosum, was found in the adult stage on both anteater species. In fact, the adult stage is restricted to members of the Myrmecophagidae family, which includes the Southern anteater and the giant anteater (PEREIRA et al., 2000; GUGLIELMONE et al., 2003; ARZUA et al., 2005). By contrast, their immature stages are bird parasites (JONES et al., 1972; LABRUNA et al., 2007; OGRZEWALSKA et al., 2009a; TOLESANO-PASCOLI et al., 2010). It is important to note that spotted fever group Rickettsia have been found in $A$. nodosum ticks parasitizing birds (OGRZEWALSKA et al., 2009b), but a link with human diseases has not yet been established. In a recent report by Almeida et al. (2013), this agent was found in A. nodosum ticks collected from anteaters in Mato Grosso do Sul.

The tick species found on domestic animals were those typically found on these hosts in Brazil. The infestation sources must have been pasture for $R$. (B.) microplus, $D$. nitens and $A$. cajennense and human dwellings for $R$. sanguineus. However, $A$. cajennense specimens may have infested dogs in forest environments as well. The absence of these tick species, with the exception of $A$. cajennense, on wild hosts may be explained by variations in the use of the study area microenvironments and tick preferences for particular hosts. The crab-eating fox, for example, can be an adequate host for $R$. sanguineus (BECHARA et al., 1995); however, it is a cautious host and does not approach human dwellings, which are a source of that tick species. However, $R$. (B.) microplus infestation of dogs that use tick-infested pasture is possible but usually restricted to few ticks (SZABÓ et al., 2001). In that case, inadequacy of the host seems to be an important restrictive factor for intense parasitism.

The lack of ticks on capuchin monkeys may also be attributed to the decreased usage of the tick-infested ground environment as well as effective self-grooming behavior. In fact, parasitism of monkeys in Brazil is often associated with wounded animals that exhibit altered behavior, including prolonged presence on the ground and decreased grooming (MARTINS et al., 2006; LAVINA et al., 2011).

On the whole, our work shows that urban areas with vegetation harbor ticks that parasitize domestic animals and wild hosts. Most of these ticks are restricted to specific microenvironments. The $A$. cajennense tick, however, is spread over several phytophysignomies of the Cerrado and in anthropized areas. This wide distribution, in addition to its high agressiveness toward various hosts, makes this tick species the most prevalent in the studied area and a vector to be closely monitored.

\section{Acknowledgements}

Embrapa Gado de Corte, CNPq and Fundect funded this work. The authors acknowledge IBAMA for granting permission to capture wild animals.

\section{References}

Almeida RFC, Garcia MV, Cunha RC, Matias J, Labruna MB, Andreotti R. The first report of Rickettsia spp. in Amblyomma nodosum in the State of Mato Grosso do Sul, Brazil. Ticks Tick Borne Dis 2013; 4(1-2): 156-159. PMid:23084365. http://dx.doi.org/10.1016/j.ttbdis.2012.08.002

Aragão HB. Ixodidas brasileiros e de alguns paizes limitrophes. $\mathrm{Mem}$ Inst Oswaldo Cruz 1936; 31(4): 759-843. http://dx.doi.org/10.1590/ S0074-02761936000400004

Arzua M, Onofrio VC, Barros-Battesti DM. Catalogue of the tick collection (Acari, Ixodida) of the Museu de História Natural Capão da Imbuia, Curitiba, Paraná, Brazil. Rev Bras Zool 2005; 22(3): 623-632. http://dx.doi.org/10.1590/S0101-81752005000300015

Barros-Battesti DM, Arzua M, Bechara GH. Carrapatos de importância médico-veterinária da região neotropical: um guia ilustrado para identificação de espécies. Sáo Paulo: Vox/ICTTD-3/Butantan; 2006.

Bechara GH, Szabó MPJ, Ferreira BR, Garcia MV. Rhipicephalus sanguineus tick in Brazil: feeding and reproductive aspects under laboratorial conditions. Rev Bras Parasitol Vet 1995; 4(2): 61-66.

Dantas-Torres F, Onofrio VC, Barros-Battesti DM. The ticks (Acari: Ixodida: Argasidae, Ixodidae) of Brazil. Syst App Acarol 2009; 14(1): 30-46.

Garcia MV, Matias J, Almeida RFC, Andreotti R. Espécies de carrapatos relatadas no estado de Mato Grosso do Sul. [online]. Embrapa Gado de Corte, 2012. [cited 2012 Nov 13]. Séries Desenvolvimento, n. 196. Available from: http://www.cnpgc.embrapa.br/publicacoes/doc/ DOC196.pdf.

Guglielmone AA, Estrada-Peña A, Keirans JE, Robbins RG. Ticks (Acari: Ixodida) of the Neotropical Zoogeographic Region. Atalanta: Houten; 2003. Special Publication of the International Consortium on Ticks and TickBorne Diseases-2.

Guglielmone AA, Beati L, Barros-Battesti DM, Labruna MB, Nava $S$, Venzal JM, et al. Ticks (Ixodidae) on humans in South America. Exp Appl Acarol 2006; 40(2): 83-100. PMid:17103085. http://dx.doi. org/10.1007/s10493-006-9027-0

Jones EK, Clifford CM, Keirans JE, Kohls GM. The ticks of Venezuela (Acarina: Ixodoidea) with a key to the species of Amblyomma in the Western hemisphere. Brigham Young Univ Sci Bull Biol Ser 1972; 17(4): 1-40.

Jongejan F, Uilenberg G. The global importance of ticks. Parasitology 2004; 129(S1): 3-14.

Labruna MB, Kerber CE, Ferreira F, Faccini JLH, De Waal DT, Gennari SM. Risk factors to tick infestations and their occurrence on horses in the state of São Paulo, Brazil. Vet Parasitol 2001; 97(1): 1-14. http:// dx.doi.org/10.1016/S0304-4017(01)00387-9

Labruna MB, Keirans JE, Camargo LM, Ribeiro AF, Soares RM, Camargo EP. Amblyomma latepunctatum, a valid tick species (Acari: Ixodidae) long misidentified with both Amblyomma incisum and Amblyomma scalpturatum. J Parasitol 2005; 91(3): 527-541. PMid:16108543. http:// dx.doi.org/10.1645/GE-446R 
Labruna MB, Pacheco RC, Ataliba AC, Szabó MPJ. Human parasitism by the capybara tick, Amblyomma dubitatum (Acari: Ixodidae). Entomol News 2007; 118(1): 77-80. http://dx.doi.org/10.3157/0013-872X(200 7) $118[77:$ HPBTCT $] 2.0 . C O ; 2$

Labruna MB. Ecology of Rickettsia in South America. Ann NY Acad Sci 2009; 1166(1): 156-166. PMid:19538276. http://dx.doi. org/10.1111/j.1749-6632.2009.04516.x

Lavina MS, Souza AP, Souza JC, Bellato V, Sartor AA, Moura AB. Ocorrência de Amblyomma aureolatum (Pallas, 1772) e A. ovale (Kock, 1844) (Acari: Ixodidae) parasitando Alouatta clamitans Cabrera, 1940 (Primates: Atelidae) na região norte do estado de Santa Catarina. Arq Bras Med Vet Zootec 2011; 63(1): 266-269. http://dx.doi. org/10.1590/S0102-09352011000100040

Martins JR, Salomão EL, Doyle RL, Teixeira MC, Onofrio VC, BarrosBattesti DM. First record of Amblyomma aureolatum (Pallas, 1772) (Acari: Ixodidae) parasitizing Alouatta guariba (Humboldt, 1812) (Primata: Atelidae) in Southern Brazil. Rev Bras Parasitol Vet 2006; 15(4): 203-205. PMid:17196126.

Martins TF, Moura MM, Labruna MB. Life-cycle and host preference of Amblyomma ovale (Acari: Ixodidae) under laboratory conditions. Exp Appl Acarol 2012; 56(2): 151-158. PMid:22113779. http://dx.doi. org/10.1007/s10493-011-9506-9

Ogrzewalska M, Pacheco RC, Uezu A, Richtzenhain LJ, Ferreira F, Labruna MB. Ticks (Acari: Ixodidae) infesting birds in an Atlantic rain forest region of Brazil. J Med Entomol 2009a; 46(5): 1225-1229. PMid:19769058. http://dx.doi.org/10.1603/033.046.0534

Ogrzewalska M, Pacheco RC, Uezu A, Richtzenhain LJ, Ferreira F, Labruna MB. Rickettsial infection in Amblyomma nodosum ticks (Acari: Ixodidae) from Brazil. Ann Trop Med Parasitol 2009b; 103(5): 413-425. PMid:19583912. http://dx.doi.org/10.1179/136485909X451744

Oliveira PR, Borges LMF, Lopes CML, Leite RC. Population dynamics of free-living stages of Amblyomma cajennense (Fabricius, 1787) (Acari: Ixodidae) on pastures of Pedro Leopoldo, Minas Gerais State, Brazil. Vet Parasitol 2000; 92(4): 295-301. http://dx.doi.org/10.1016/S03044017(00)00322-8
Oliveira Filho AT, Ratter JA. Vegetation physiognomies and woody flora of the cerrado biome. In: Oliveira PS, Marquis RJ, editors. The cerrados of Brazil: Ecology and Natural History of a Neotropical Savanna. New York: Columbia University Press; 2002. p. 91-120.

Pereira MC, Szabó MPJ, Bechara GH, Matushima ER, Duarte JMB, Rechav Y, et al. Ticks (Acari: Ixodidae) associated with wild animals in the Pantanal region of Brazil. J Med Entomol 2000; 37(6): 979-983. http://dx.doi.org/10.1603/0022-2585-37.6.979

Spolidorio MG, Labruna MB, Mantovani E, Brandão PE, Richtzenhain LJ, Yoshinari NH. Novel spotted fever group rickettsiosis, Brazil. Emerg Infect Dis 2010; 16(3): 521-523. PMid:20202436 PMCid:3322033. http://dx.doi.org/10.3201/eid1603.091338

Szabó MPJ, Olegário MMM, Santos ALQ. Tick fauna from two locations in the Brazilian savannah. Exp Appl Acarol 2007; 43(1): 73-84. PMid:17828441. http://dx.doi.org/10.1007/s10493-007-9096-8

Szabó MPJ, Cunha TM, Pinter A, Vicentini F. Ticks (Acari: Ixodidae) associated with domestic dogs in Franca region, São Paulo, Brazil. Exp Appl Acarol 2001; 25(10-11): 909-916. PMid:12455880. http://dx.doi. org/10.1023/A:1020433003028

Szabó MPJ, Nieri-Bastos FA, Spolidorio MG, Martins TF, Barbieri AM, Labruna MB. In vitro isolation from Amblyomma ovale (Acari: Ixodidae) and ecological aspects of the Atlantic rainforest Rickettsia, the causative agent of a novel spotted fever rickettsiosis in Brazil. Parasitology 2013. In press. PMid:23363571. http://dx.doi.org/10.1017/ S0031182012002065

Tolesano-Pascoli GV, Torga K, Franchin AG, Ogrzewalska M, Gerardi $\mathrm{M}$, Olegário MMM, et al. Ticks on birds in a forest fragment of Brazilian cerrado (savanna) in the municipality of Uberlândia, State of Minas Gerais, Brazil. Rev Bras Parasitol Vet 2010; 19(4): 244-248. PMid:21184702. http://dx.doi.org/10.1590/S1984-29612010000400010

Veronez VA, Freitas BZ, Olegario MMM, Carvalho WM, Pascoli GVT, Thorga K, et al. Ticks (Acari: Ixodidae) within various phytophysiognomies of a Cerrado reserve in Uberlândia, Minas Gerais, Brazil. Exp Appl Acarol 2010; 50(2): 169-179. PMid:19693680. http:// dx.doi.org/10.1007/s10493-009-9294-7 